\title{
Social Space of the Regional City and a Development of Roman-Catholic Parishes in Socio-Historical Aspect
}

\author{
Prof. Dr. Witold Jedynak \\ Institute of Sociology, Rzeszów University \\ vox321@interia.pl
}

Doi:10.5901/mjss.2014.v5n13p417

\begin{abstract}
In Poland, the Roman Catholic parish is a common and most stable local socio- religious institution which is an important part of life of the inhabitants of cities, towns and villages. It seeks to meet the basic needs of religious believers, and usually leads social, cultural and charitable roles. An important element of the parish community becomes the bond formed between the faithful, defined as lasting sense of identification with the local community and inhabited by her territory. In Poland, in the postwar period, followed by a rapid development of the industry, were created in large cities, which resulted in a change in the socio- demographic structure of the population. At that time the country was in the zone of influence of the Soviet Union, and the state power exercised Communists who created a repressive totalitarian system. Only after the fall of communism in 1989 , and the change of regime Poland is among the countries that build democracy consent to the standards of civil society. Conducted sociological studies showed that in Rzeszów since the mid-sixties, followed by a dynamic development of the structures of the parish, and the parish has become an important center for the faithful of socio -religious. The presentation includes the results of empirical studies, which are an example of the development of structures in the regional church in Poland, along with a comparative analysis of the dynamics of socio- demographic changes .
\end{abstract}

Keywords: sociology, social sciences, regional development, Roman Catholic parishes, regional city

\section{Introduction}

In Poland, a Roman Catholic parish is a common and most stable local institution, which plays a primary role in the lives of residents of cities, towns and villages. A parish - a basic unit within the structure of Roman Catholic Church is a subject to nonstop influence of various social processes. In Poland, after the Second World War, both the industry and big cities developed rapidly, what affected the social and demographic structure of the country population. Back then, Poland was in the Soviet Union zone of interest, power was held by the communists who created a repressive totalitarian regime. Only after 1989, when the communism had fallen and the system had changed, did Poland become one of the democratic states, building a civil society.

A Roman Catholic parish within a rapidly changing social situation in Poland is a very interesting subject of research considering both the period of the communists oppressive policy on religion, and the following twenty years in an already democratic Poland. At that time, in Western Europe, in the realms of society modernization and religion privatization, the process of secularization escalated and resulted in the decreasing influence of religion on public life. Ever since, the power of religion and its institutions (parishes, too) is dwindling, as well as their ability to affect various segments of social network. Due to pluralism and individualism, religion becomes more and more a personal matter, and every person uses it with regard to their special needs. This results in limiting the impact of Roman Catholic Church on social life, as well as in separating religion from morality, religious subjectivism and in accepting only selected articles of faith. The bond between believers and their parish weakens, churches become empty, some are even transformed into museums, culture centres, and some are sold and intended for public utility (e.g. for shops, shopping centres).

The dynamic, both spatial and demographic development of Rzeszów was coupled with industrialization, modernization, technical progress and Weber's rationalization. As a result, there appeared basic factors which, according to the renowned sociologists (such as Max Weber, Emil Durkheim, Peter Berger and Thomas Luckmann), support society secularization. What is more, during the communist era, the government attempted to eliminate religious institutions, especially those of Roman Catholic Church. Religion was fought against administratively and the main objective of this oppressive policy was the complete atheization of the society. It was obvious that these methods were designed to strengthen secularization trends consistent with the lay Leninist society paradigm. Thus emerge extraordinarily interesting research problems: To what changes was a Roman Catholic parish in Rzeszów a subject in the times of modernity? Was the religious and social role of a Roman Catholic parish in the intensively modernized and administratively atheized 
society of Rzeszów dwindling since the 1960s (when the sociology of religion was dominated by the argument on secularization)?

The research presented in this article was based on primary and secondary sources. The primary sources are, among others: source materials from parish archives (statistical data, parish reports, parish registers, chronicles etc.) and data published by the Central Statistical Office of Poland (GUS) and the Institute of Catholic Church Statistics (SAC). The secondary sources are: 40 qualitative interviews with a diocese bishop emeritus and with the former and present parish priests of Rzeszów parishes, or with people appointed by them.

\section{The Dynamic, Spatial and Demographic Development of Rzeszów}

Two months after the Second World War was over, on 7 July 1945, Polish authorities issued a decree in which Rzeszów was appointed the capital city of a voivodship. This decision had a significant effect on the city comprehensive development. The communist elite of Rzeszów wanted it to be the symbol of the authorities success and a model socialist city. The city socialist character and the supremacy of people's government was to be emphasized by the massive socrealistic edifices, the monument of the Revolutionary Deed seated on the junction of two main roads, the huge panel blocks of flats and industrial plants. The spatial, industrial, social and demographic development of Rzeszów was a priority. The growing administrative importance of Rzeszów meant creating many offices and public institutions, and establishing the city as the centre of the region political and cultural life. People from different milieus arrived, artists, people who organized new local authorities and arranged the city space. The city prestige was enhanced by schools, large academic centres, and big production plants offering employment and housing. Because many industrial and trade centres came into being, the demand for workforce increased within various professions. Both the city residents and people from neighbouring villages came to Rzeszów to work and live in the newly built housing estates.

The population changed under the influence of many factors. The most important ones (between 1946 and 1989) were the migration (about 47\%), population growth (about 30\%) and the modification of administrative division (about $23 \%$ ). The size of migration was impressive - by the end of the 1970s almost $75 \%$ of Rzeszów residents were not native to the city ${ }^{1}$. This process continued with a varied intensity up to the end of the 1980s and was inhibited in the 1990s by the beginning of political transformation in Poland. In the 1990s, the influx of new inhabitants declined by $50 \%$ and was accompanied by constant emigration (Malikowski, 1989: 96-100; Idem 1991: 152; Solecki, 2002:126-127).

However, the population of Rzeszów was incessantly growing because of the high population growth. Throughout the post-war period, up till the 1980s, Rzeszów was, demographically speaking, a young city.

The population size depends on the city territorial expansion onto neighbouring villages which make an attractive residential area. Between 1951 and 2010, the borders were expanded four times by annexing neighbouring villages. As a result, the area of Rzeszów increased fourteen times, for in 1951 it amounted to $8 \mathrm{~km}^{2}$, and now it comes to $116 \mathrm{~km}^{2}$. The biggest territorial expansion took place between 2006 and 2010, and it amounted to $62.68 \mathrm{~km}^{2}$, that is $54 \%$ of the city current territory (Malikowski 1991: 153; Urząd Miasta Rzeszowa).

Diagram 1. The population dynamics in Rzeszów, 1945-2012.

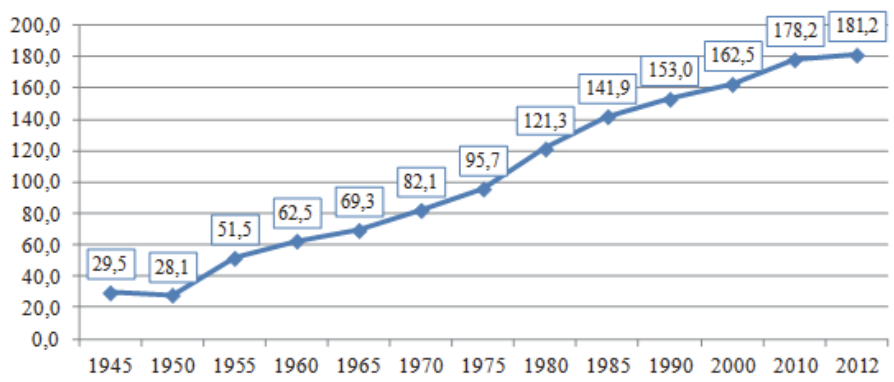

Source: Own study on the basis of: Roczniki Głównego Urzędu Statystycznego (Central Statistical Office Yearbooks), Malikowski, 1991, pp. 151-155; Bonusiak, 2010, pp. 144-145.

As mentioned above, the migration, population growth and territorial expansion decided on the size of Rzeszów

${ }^{1}$ By native to the city the author means 'born in Rzeszów'. 
population. The increase in the number of residents was one of the elements that created this big regional centre. In 1950, the city population amounted to 28,100, and in 2012 it came to 181,200, so it increased sixfold. The highest population growth dated between 1970 and 1990, and amounted to 70,900. The most important factors which stimulated this influx were: (1) low degree of urbanization of areas where the immigrants came from; (2) Rzeszów attractiveness in view of lack of other big cities nearby and (3) local government policy which favoured selective migration. Currently, the city is divided into 29 districts. (Malikowski 1991:151-155; Idem 1989: 21-23, 87-100; Bonusiak, 2010: 144-145; Urząd Miasta Rzeszowa).

\section{The Reorganization of Parishes in Rzeszów}

The dynamic spatial and demographic development of Rzeszów was a new and difficult challenge to the parish ministry. Together with the construction of big housing estates, especially panel blocks of flats, on a one parish territory, the number of residents grew quickly. The parish was no longer able to serve its purpose, that is to meet the religious needs of Roman Catholics. Creating new units of church administration was a necessity. In 1949, two new parishes were established in Rzeszów, and two years later a rural parish was annexed by the city and the number of parishes amounted to four. Despite growing religious needs, no new parish was established for the next fourteen years in Rzeszów, due to the policy on religion of the governing party. The communist activists and urbanists assumed that the city would be of purely socialist character and that no new sacral buildings or units of church administration would be created. In order to carry out these plans, only the activists of merit were summoned to Rzeszów to implement an oppressive policy on religion, especially towards Roman Catholic Church. That is why in 1966, in the city of 70,000 residents there were only four parishes (Rocznik diecezji przemyskiej, 1952: 46, 101-102; Rocznik diecezji przemyskiej, 1966: 123-125; W. Bonusiak: 145).

The implementation of this utilitarian, but slightly unrealistic in the reality of a totalitarian regime, strategy was quite difficult in view of the communist authorities resistance. When establishing new parishes, the biggest ones - those of the largest population - were divided. Despite numerous difficulties, most of all Rzeszów parishes were established in the 1970s and 1980s. In June 1991, there were 22 parishes in the city, three of which had more than 10,000 parishioners $(11,000,11,600$ and 15,000). Eighteen of them were established after 1945, during the period of a cold war between the totalitarian regime and Roman Catholic Church. By implementing the plan of organizing parish structure in Rzeszów, the church authorities, together with the laymen from the already existing parishes, delimited new parishes. In the meantime, new churches were built in every new parish thanks to the parishioners, although the spatial plan did not include any new sacral buildings (Schematyzm diecezji przemyskiej, 1991: 262-282; Wierzbieniec, 2005: 75).

After the communism had fallen, during the political transformation accompanied by the democratization of public life and by the emergence of civil society, the parish structure in Rzeszów developed without much ado and with the help of residents - accordingly to their needs, activities and finances. This process of parish structure concentration is continued since 1992 by the bishop of Rzeszów, Kazimierz Górny (Pierwszy Synod Diecezji Rzeszowskiej, 2004: 47-49, 79; Nabywaniec, 2010: 167-169).

Figure 1. An outline of Rzeszów parishes in $2010 .^{2}$

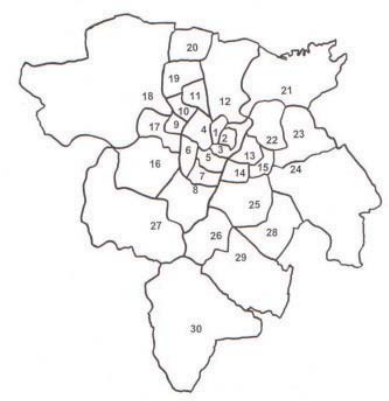

2 The position of a number indicates the location of a parish church in the city. 
Source: Own study on the basis of a current plan of Rzeszów.

Table 1. Figure legend

\begin{tabular}{|c|c|c|}
\hline No. & Parish & Number of parishioners in 2010 \\
\hline 1. & The Assumption of Virgin Mary (Franciscans) & 4,355 \\
\hline 2. & The Holy Cross & 2,500 \\
\hline 3. & St Adalbert and St Stanislaus & 2,900 \\
\hline 4. & Christ the King & 7,000 \\
\hline 5. & Mother of God Queen of Poland (civil and military) & 5,500 \\
\hline 6. & St Jude the Apostle & 8,200 \\
\hline 7. & Our Lady of La Salette (the La Salettes) & 8,900 \\
\hline 8. & St Hyacinth (Dominicans) & 3,800 \\
\hline 9. & The Holy Family & 7,600 \\
\hline 10. & The Exaltation of the Holy Cross & 5,800 \\
\hline 11. & Our Lady of the Rosary & 7,000 \\
\hline 12. & St Joseph (Rzeszów-Staromieście) & 8,300 \\
\hline 13. & St Jadwiga of Poland & 4,100 \\
\hline 14. & The Divine Providence (Salesians) & 7,720 \\
\hline 15. & Michael the Archangel & 5,950 \\
\hline 16. & The Nativity of Virgin Mary (Rzeszów-Staroniwa) & 1,920 \\
\hline 17. & Blessed Karolina Kózka & 4,000 \\
\hline 18. & St Nicholas (Rzeszów-Przybyszówka) & 3,300 \\
\hline 19. & Corpus Christi and Our Lady of Lourdes & 8,220 \\
\hline 20. & St Hubertus (Rzeszów-Miłocin) & 1,600 \\
\hline 21. & Our Lady of Perpetual Help and St Florian (Rzeszów-Załęże) & 1,400 \\
\hline 22. & St Józef Sebastian Pelczar the Bishop (Rzeszów-Pobitno) & 5,300 \\
\hline 23. & St Joseph Calasanctius (Rzeszów-Wilkowyja) & 4,250 \\
\hline 24. & St Roch (Rzeszów-Słocina) & 5,200 \\
\hline 25. & The Sacred Heart of Jesus (cathedral) & 10,500 \\
\hline 26. & Our Lady of Częstochowa & 1,088 \\
\hline 27. & St Joseph (Rzeszów-Zwięczyca) & 2,850 \\
\hline 28. & The Assumption of Virgin Mary (Rzeszów-Zalesie) & 3,810 \\
\hline 29. & The Divine Mercy (Rzeszów-Biała) & 2,104 \\
\hline 30. & Our Lady of the Snows (Rzeszów-Budziwój) & 3,650 \\
\hline \multicolumn{2}{|r|}{ 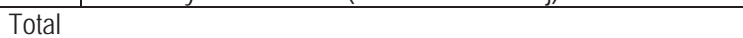 } & 148,817 \\
\hline
\end{tabular}

Source: Own study.

In order to meet the parishioners needs, the church authorities established four new parishes between 1995 and 2006. What is more, between 2006 and 2010, four rural parishes were annexed by the city. Consequently, at the end of 2010, there were 30 parishes on the territory of 29 city districts with 178,000 residents, 149,000 of which were Roman Catholic (that is $84 \%$ of the city population), on $116 \mathrm{~km}^{2}$. Statistically, an average parish area comes to $4 \mathrm{~km}^{2}$, while an average number of parishioners in one parish amounts to almost 5,000. In reality, the number of parishioners in each parish varies greatly. There are eight parishes in the city with less than 3,000 parishioners. It should be mentioned that the first and the oldest Rzeszów parish was one of the most populated parishes in the 1950s and 1960s (over 30,000 parishioners), and is now one of the less populated (2,900 parishioners). In addition, within the city borders, there are eight parishes with 3,000-5,000 parishioners, six parishes with 5,000-7,000 parishioners and eight parishes with more than 7,000 parishioners, and only one of the latter is of more than 10,000 parishioners (the cathedral parish - 10,500 parishioners). Twenty four parishes are under the care and jurisdiction of diocesan priests, six remaining are led by priests from monasteries and congregations. One of the greatest achievements of Rzeszów parishes is good infrastructure and not too extensive territories, as the distance to all parish churches is less than $4 \mathrm{~km}$. Obviously, it would be best if the parish territory overlapped the district, and if the parish church was situated in the centre of a district. Unfortunately, in many Rzeszów parishes, especially those situated in the city centre, this rule was not observed, and for this reason the parish borders divide the districts. The situation is much better in the former rural parishes lately annexed to Rzeszów, because their territories overlap the districts, however, most of the parish churches lie out of the district centre (Own calculations on the basis of: Schematyzm diecezji rzeszowskiej from 01.12.2010). 
Diagram 2. The growing number of parishes in Rzeszów, 1945-2010.

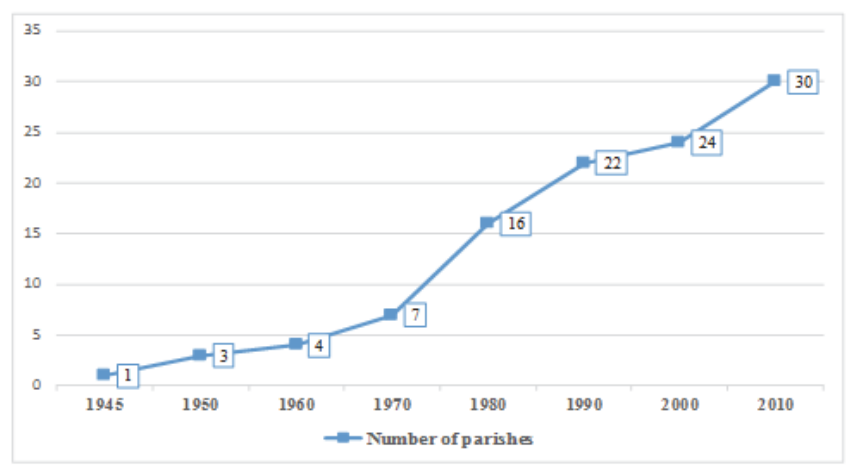

\section{Source: Own study.}

Establishing new parishes affected the number of priests in Rzeszów. In 1984, there were 19 parishes in the city (with 138,648 parishioners) with 84 priests, so statistically there was one priest per 1,651 parishioners. There were 61 diocesan priests in 15 parishes, and 23 monastic priests in 4 parishes. After the reorganization of Polish dioceses in 1992, Rzeszów became the capital city of the Rzeszów diocese and the number of priests increased, as they were involved not only in parish work, but also employed in many church offices. In 1993, 2 bishops and 132 priests, including 49 monastic priests, lived in 22 Rzeszów parishes. In 2000, the city was divided into 24 parishes with 157 priests, what made one priest per 919 parishioners. At the end of 2010, there were 2 bishops, 208 priests ( 30 parish priests, 58 vicars and 120 other clergymen) within 30 Rzeszów parishes. Statistically, there is 7 clergymen per one parish of 5,000 parishioners, that is one priest per 714 parishioners. The relatively high number of priests results from the city being the capital of a diocese. There are many diocesan institutions in Rzeszów, where the clergymen fulfil various functions. The diocesan priests account for $71 \%$ of all clergymen, whereas monastic priests for $29 \%$. Diocesan priests serve in 24 parishes, while priests from monasteries and congregations (the La Salettes, Franciscans, Piarists, Salesians, Missionaries of the Holy Family, Dominicans) serve in 6 parishes. Most of the priests (25) live in a parish led by diocesan priests, where a Senior Priests Home is located. Except for that one parish, it is the monastic parishes which excel in the number of priests, and this has a great impact on the specific character and quality of pastoral service. In most parishes, the vicars or other clergymen help the parish priests in their work. There are 3 parishes in Rzeszów, where there is only one priest. Between 1984 and 2010, the number of priests in Rzeszów increased by 148\% (diocesan priests - by 143\%, monastic priests - by 161\%) (Own calculations on the basis of: Rocznik diecezji przemyskiej na rok 1984 (ed. H. Borcz): 1984; Schematyzm diecezji rzeszowskiej 1993; Schematyzm diecezji rzeszowskiej 2000; Schematyzm diecezji rzeszowskiej 2010).

\section{The Activity of Parishioners While Establishing New Parishes}

The spatial development of Rzeszów, the growing number of residents and the reorganization of parish structure made it necessary to build new sacral buildings. The biggest agglomerations of Roman Catholics were the housing estates of panel blocks of flats. Thus the necessity of building churches and chapels, so that each local Roman Catholic community had their own temple. Sacral buildings were supposed to lay the foundation for the parishioners spiritual life and various congregations of laymen. New churches were particularly in demand in the big housing estates where people from rural areas settled in new apartments, together with their traditional religious models based on the faith of their fathers. Their religiosity was closely connected to the institutional Church which prescribed a model of religious life combining values, rules and religious behaviour patterns, as well as roles to be performed by its members. Both the attitudes and behaviour of lay believers were shaped to fit the model of life promoted by the Church and all related expectations. The priest, as a representative of the hierarchic Church, enjoyed respect of the local community (W-1, W-10, W-19).

In the People's Republic of Poland, the development of churches chain was inhibited by the local authorities and security service which by implementing the communist policy on religion limited the pastoral activity of the Church. The city authorities applied various methods to obstruct the construction of new temples. Their strategy was usually delaying 
and hampering all procedures related to sacral building, and then issuing a negative decision. The decision was most often motivated by the lack of building materials or of demand for new churches. Office clerks were really persistent when issuing permits for the construction of sacral buildings in new housing estates. The nuisance caused by music, chanting and bells was the reason for negative decision - such a building should not be located in the middle of a modern housing estate. Besides, the law did not see a church or a chapel as a building of public utility, so it could not be a part of the spatial plan and the possibility of obtaining a parcel of land was virtually none. These made up impediments were a cover-up for the communist policy of gradual atheization of the society. The parishioners, however, were not easy to intimidate or discourage. At that time, the neglect of society basic religious needs was the source of serious conflicts with the authorities during the construction of parish churches in Rzeszów (W-19, W-22, W-23. See: S. Bober, Persona non grata. Biskup Ignacy Tokarczuk i władze PRL, wyd. 1, Lublin 2005: 146-151, 206-221; A. Garbarz, Działalność duszpastersko-społeczna arcybiskupa Ignacego Tokarczuka, Rzeszów 2006: 312-317).

The development of sacral building in Rzeszów, both in the communist era and in the following two decades, was very dynamic. Between 1975 and 2010, 22 parish churches were built or extended in Rzeszów. Nowadays, within all Rzeszów parishes, there are 30 parish churches, 4 succursal churches and 28 chapels. Often, these monumental buildings are a part of a pastoral centre. All parishes, with one exception, have their own temples to meet the needs of their parishioners. The youngest parish is currently building a church, though it has a wooden chapel where the masses are said.

Most of the city churches were built after 1980. Previously, the temples were located in temporary, improvised chapels. In Rzeszów, sometimes, the chapels were arranged in private houses or quickly constructed barracks. They were secretly prepared and then consecrated by one of the bishops. These chapels were illegal, so the parishioners stayed in for days, and nights, praying and preventing security service from seizing the building. (W-10; W-2; W-21, W27; Schematyzm diecezji rzeszowskiej 2010)

The development of parish structure in Rzeszów had a great influence on the parishioners activity. The cooperation of priests and laymen in establishing the parishes and constructing churches released the spirit of diligence, generosity and dedication, and brought back self-confidence. Carrying out an uneasy, both financially and logistically, task required teamwork and a big share of time. Solidary co-operation strengthened the ties among parishioners and priests. The authority of priests was built up, as well as their role in the local community. Many people felt more emotionally connected to a church built at such an expense of their money and labour. Sharing this effort was an opportunity to get into relation with each other, it intensified devotion for common cause and deepened attachment to one's own parish even in the not so much religious people. Engaging almost all of the parishioners in the life of a parish was a chance to integrate local community and to promote being active, not only spiritually, but also socially and patriotically. Many of those who were, so far, passive and anonymous started to act, to perform various roles in their parishes and local communities. Both the newly established parishes and newly built churches were very important as stabilizing and integrating factors in the new housing estates. ${ }^{3}$ New residents, relocating from the countryside to the city, were especially threatened with the loss of traditional local ties and progressive isolation. Besides, the inhabitants of housing estates were menaced by the negative effects of industrialization and urbanization, which made attitudes, behaviour, and ethical and religious values relative. Establishing new parishes made it possible to meet the residents basic religious needs and to sustain their attachment to Roman Catholic faith and tradition, according to their family custom. What is more, participating in the parish temple construction was a chance to enter into stable social relations, to integrate with a new place of residence, to put down roots, to bond with the parish. It was also affecting the intensity of religious practices and shaping moral attitudes. Thanks to establishing new parishes and erecting many temples, the local Church grew bigger and stronger. New churches became the premises of numerous prayer groups, associations and confraternities which activities showed the growing commitment of parishioners in the life of their parish, as well as in the local and regional community. (W-1; W-10; W-28; Bełch, 1990: 201-203; Szareyko, 1994: 92-104).

Within the local parish communities of Rzeszów, the continuity of social processes is accompanied by their transformation and modification on the social basis closely connected to the community tradition. The past has a tremendous impact on the lives of city residents, who inherit particular values and customs. Sociological research confirm that this strong and vivid religiosity of Rzeszów residents is quite specific, and religion is still one of the key elements of their identity.

The percentage of dominicantes and communicantes is an important indicator of Rzeszów parishes religiosity. The dominicantes ratio is the percentage of parishioners present at a Sunday mass in comparison to the total number of parishioners within the given territory. For all of the parishes in Poland, it was presumed by the Institute of Catholic

${ }^{3} \mathrm{~A}$ parish was usually the first integrating agent within the new social space and diverse population structure. 
Church Statistics SAC that parishioners obligated to participate in Sunday masses account for $82 \%$ of the total number of parishioners. The remaining $18 \%$ are Roman Catholics who for various reasons have no legal (canonical) or moral duty to participate in a mass (e.g. children under the age of 7; old, disabled or ill people, etc.). Because there is always a group of parishioners among the dominicantes which receives Holy Communion, so there is the possibility of determining the second important religiosity indicator. It is the communicantes ratio - the percentage of parishioners who take Communion in comparison to the total number of those obligated to participate in a Sunday mass. (Zdaniewicz, Adamczuk, 2000: 451-452; Gudaszewski, 2006: 73-74).

The collected statistical data made it possible to determine that in 2010,80,000 parishioners took part in selected Sunday masses, what accounts for $54 \%$ of all Rzeszów parishioners. According to the methodology of the Institute of Catholic Church Statistics, the dominicantes ratio amounted to $65.6 \%$ and was slightly lower than the dominicantes ratio for Rzeszów diocese, which amounted to $66.8 \%$. At the same time, the dominicantes ratio in Poland came to $41 \%$. When comparing these dominicantes ratios, one can notice that Rzeszów parishioners are much better at performing their duty of a Sunday mass presence than average Poles, thus it can be deducted that they feel more closely connected to their parishes. (Own study. Compare: Sadłoń, 2010; Gudaszewski, 2006: 77-106)

During that Sunday survey in Rzeszów parishes, 22,464 parishioners took Communion, what accounts for $15.1 \%$ of all the parishioners and for $18.4 \%$ of those obligated. This result is almost identical to the result of the Institute of Catholic Church Statistics for Rzeszów diocese, where the communicantes ratio amounted to $18.3 \%$ of the obligated in 2010. Same year, the communicantes ratio in Poland came to 16.4\%. (Own study. Compare: Sadłoń 2010).

From what Rzeszów parish priests gather, in the last few years a slight increase of the communicantes ratio goes hand in hand with a decline of dominicantes ratio. This trend is confirmed by the results of national research. The upward trend of the communicantes ratio indicates that religiosity of many people becomes more mature and deepened as they try to truly participate in a mass and receive Communion. The communicantes ratio is also growing because of the responsible and active involvement in the activities of parish groups and associations. Their members consolidate their communion with God and neighbours through spiritual and intellectual formation, and active participation in parish life. (W-2; W-10; W-36).

The bond between the parishioners and the Church is expressed through taking part in the activities of local Catholic groups and associations. Being an active parishioner means involving in the Church apostolic mission of ensuring that Christian rules are permeating the entire human existence. That way parishioners can oppose secularization and privatization of religion, affecting modern society, and bring back sacrum into the public. They also show the potential of Roman Catholic religion in times of social modernity. The place where laymen can really engage themselves in the Church life is a parish. Parishioners participate in its microstructures and become members of religious communities and associations. Thus, the Roman Catholic laity becomes co-responsible for the parish, co-operates with the clergymen and supports them in various activities and initiatives designed for the common good.

In 2010, there were about 420 groups (representing 90 associations and movements) in Rzeszów parishes with about 28,500 members (19\% of all city parishioners). Usually, parishioners organize themselves in Parish Pastoral Councils, Parish Caritas Teams, the Living Rosary, Catholic Action, the Domestic Church, Catholic Families Associations, both Radio Maryja and Radio Via Friends Associations, the Friends of the College Seminary Association, Parish Choirs. Young people prefer: the Light-Life Movement, Catholic Youth Association, Altar Servers, Academic Pastoral Care, Parish Scholas. Temperance movement plays a very important role in local parish communities, especially the Crusade for the Liberation of Man. Organizing such groups and associations is recommended by the Synod of Rzeszów Diocese (According to own study).

In an industrialized and urbanized society, contemporary Rzeszów parishes try to oppose secularization and religion privatization. Their activity is aimed at the development of parishioners spiritual life, desecularization and deprivatization. What is more, it shows the potential of Roman Catholicism which can effectively affect modern society. The parish evangelization activity is not limited to tasks typical of religious and church institutions (these are the basic forms of the Church presence in public life), but it endeavours to include the most important aspects of human life. Parishes promote Christian culture, support patriotic and religious organizations, inspire charity, launch prevention campaigns, help the addicts, run kindergartens and social therapy centres, organize summer camps for children, care for parishioners intellectual formation, co-operate with local government units and other institutions. Of course, church infrastructure does not serve only the religious needs of the parishioners, but also the cultural ones. Very often, national holidays and local festivities are celebrated in the churches or parish houses. Concerts are held there, as well as exhibitions, lectures, symposia, performances, commemorative meetings, meetings with special guests, and Christmas parties for various groups and associations etc. (W-2; W-8: W-27; W-36).

Despite many pastoral events taking place in Rzeszów parishes, the bond between parishioners and their parish is 
loosening. Both the political transformation, and the society adaptation to a liberal and consumer way of life have caused changes in Rzeszów parishes. Part of laymen do not identify themselves with their parish, and do not get involved in the parish life, apart from formal matters. Those people see their parish as a sort of religious service agency. A modern parish is a place where the paradigm of evangelism and the paradigm of secularization meet. The process of religion privatization is developing. Nowadays, every person decides where is religion in their lives, is it important or is it not? More and more parishioners prefer loose relationship with their parish, they only declare themselves as Roman Catholics and formally appear in parish books. Believers do not identify religiosity with the Church, it is their business. Part of Rzeszów residents, especially the young ones, do not act according to objective and universal moral rules, but are guided by their subjective and conformist convictions. There is a dissonance between both the fundamental articles of faith, and the common philosophy of life and behaviour of the baptized. The involvement of many Roman Catholics in the life of local parish communities is usually shallow, because its form is usually traditional and superficial (W-2, W-19, W-23; W36) Zob. Mariański 1997: 143-164; Idem, 2004 (a): 69-71; Idem, 2004 (b): 344-361).

\section{Conclusion}

Rzeszów is undoubtedly a very interesting subject of research for a religion sociologist, as it is the only voivodship city where the city development was accompanied by the development of parish structure, despite oppressive communist policy on religion. What was a true social phenomenon, was establishing new parishes and building new churches without legal permits, as the communist authorities would not issue one. The authorities did their best to transform Rzeszów into a leading socialist city without pastoral centres and churches. Nevertheless, these actions were to no avail, and new parishes and new temples were erected despite reprisals and penalties. Owing to the determination of local clergymen and laymen, on entering new, democratic reality Rzeszów had well-organized parish structure, unlike other Polish cities with parishes of several thousand or even a hundred thousand parishioners. In the following years, depending on Rzeszów residents needs, the structure of parishes was reorganized. In 2011, there were 30 parishes in the city, all of diverse territory and number of parishioners.

The process of creating smaller parishes, both in terms of space and population, improved the church structure functionality. Smaller units were more effective in meeting the parishioners religious needs and in strengthening the parish community ties. This was extremely important when the authorities attempted to fight off religion, as it helped local parish communities to survive, and boosted laymen religious and public activity.

The transformation of a Roman Catholic parish in Rzeszów shows that industrialization, social modernization, technological progress and rationalization did not implicate secularization of the city. From the early 1960s to the end of 1980s, an inverse trend could be observed, as both the religiosity and the parish activity of the Rzeszów laymen was very dynamic. Minor changes in Rzeszów Roman Catholics attitudes and behaviour are noticed since 1995. These include a slight decrease in the number of parishioners participating in Sunday masses, accompanied by an increase in the number of parishioners receiving Communion. Furthermore, the bond with the parish is weakening and the parishioners morality is no longer so strictly based on the rules of Roman Catholic Church. The sociological research indicate the growing discrepancy between the real moral attitudes of Roman Catholics, and their general religious declarations and the Church doctrine.

\section{References}

Bełch K. 1990. Dynamika przemian zachowań religijno-moralnych w warunkach tworzenia nowych parafii. Studium socjologiczne na przykładzie diecezji przemyskiej w latach 1966-1985, Przemyśl: Authors support.

Bełch K. 1993. „Wprowadzenie”. Pp. 3-16 in: Nowe kościoły diecezji przemyskiej w jej dawnych granicach powstałe w latach 1966-1992, Przemyśl: Kuria Diecezjalna

Bober S. 2005. „Persona non grata. Biskup Ignacy Tokarczuk i władze PRL”, wyd. 1, Lublin

Bonusiak W. 2010. „Rozwój demograficzny Rzeszowa w latach 1945-1989”. Pp. 144-152 in: Rzeszów - w 655. rocznicę lokalizacji. Studia z dziejów miasta i regionu, edited by W. Bonusiak, W. Zawitkowska, Rzeszów: Wydawnictwo Uniwersytetu Rzeszowskiego

Garbarz A. 2006. Działalność duszpastersko-społeczna arcybiskupa Ignacego Tokarczuka, Rzeszów 2006: Poligrafia Wyższego Seminarium Duchownego w Przemyślu

Gudaszewski G., „Statystyka praktyk niedzielnych dominicantes i communicantes w diecezjach”. Pp. 73-106 in: Statystyka diecezji Kościoła katolickiego w Polsce 1992-2004, edited by: L. Adamczuk, W. Zdaniewicz, S. H. Zaręba. Warszawa: Instytut Statystyki Kościoła Katolickiego SAC

Majka J. 1971. „Socjologia parafii. Zarys problematyki”. Lublin: KUL

Malikowski M. 1991. „Powstawanie dużego miasta. Drogi i bezdroża socjalistycznej urbanizacji na przykładzie Rzeszowa”. Rzeszów: 
Wyższa Szkoła Pedagogiczna w Rzeszowie

Malikowski M. 1989. „Rzeszów - awans i aspiracje”. Rzeszów: Wyższa Szkoła Pedagogiczna w Rzeszowie

---. 1961. Mały rocznik statystyczny województwa rzeszowskiego 1961. Rzeszów: Prezydium Wojewódzkiej Rady Narodowej w Rzeszowie

Mariański J. 2004a. „Deinstytucjonalizacja a religia”. In: Leksykon socjologii religii, edited by: M. Libiszowska-Żółtkowska, J. Mariański. Warszawa: Verbinium

Mariański J. 1997. „Religia i Kościół między tradycją i nowoczesnością. Studium socjologiczne”. Kraków: Nomos

Mariański J. 2004b. „Religijność społeczeństwa polskiego w perspektywie europejskiej. Próba syntezy socjologicznej”. Kraków: Nomos

Nabywaniec S. 2010. „Rzeszów w roli stolicy nowej diecezji obrządku łacińskiego na Podkarpaciu”. Pp 166-169 in: Rzeszów - w 655.rocznicę lokacji. Studia z dziejów miasta i regionu, edited by: W. Bonusiak, W. Zawitkowska, Rzeszów: Wydawnictwo Uniwersytetu Rzeszowskiego

---, 2004. „Pierwszy Synod Diecezji Rzeszowskiej”. Rzeszów: Wydawnictwo Diecezji Rzeszowskiej

---.1991. „Podstawowe dane statystyczne według miast i gmin za 1990 r.”. Rzeszów: Wojewódzki Urząd Statystyczny w Rzeszowie

---.1952. „Rocznik diecezji przemyskiej na rok 1952”, Przemyśl: Kuria Diecezjalna

---.1966. „Rocznik diecezji przemyskiej na rok 1966”, Przemyśl: Kuria Diecezjalna

Borcz H(ed.).1984. „Rocznik diecezji przemyskiej na rok 1984”. Przemyśl: 1984

----1982. „Roczniki statystyczne województwa rzeszowskiego 1981”. Rzeszów: Wojewódzki Urząd Statystyczny w Rzeszowie

Klisko A (ed.) . 1991. „Schematyzm diecezji przemyskiej 1990. Terytorium - Duchowieństwo - Instytucje (by the date $30 \mathrm{VI}$ 1991)",Przemyśl: Kuria Diecezjalna

Schematyzm diecezji rzeszowskiej 2010. „Schematyzm diecezji rzeszowskiej 2010. (by the day 01.12.2010)”, Rzeszów: Poligrafia Wyższego Seminarium Duchownego

Schematyzm diecezji rzeszowskiej 1993. „Schematyzm diecezji rzeszowskiej 1993” Rzeszów: Wydawnictwo Diecezji Rzeszowskiej

Schematyzm diecezji rzeszowskiej. „2000. Wydanie jubileuszowe na Wielki Jubileusz Wcielenia (stan z dnia 25 marca 2000)”, Rzeszów: Wydawnictwo diecezji rzeszowskiej

Solecki S. 2002. „Mobilność przestrzenna ludności Rzeszowa w okresie przemian systemowych”. Pp. 119-138 in: Społeczeństwo Podkarpacia na przełomie wieków, edited by M. Malikowski. Rzeszów: Towarzystwo Naukowe w Rzeszowie

Szareyko H.1994. „Współdziałanie społeczności wiejskich przy nielegalnej budowie obiektów sakralnych diecezji przemyskiej w latach 1966-1980", Warszawa: Ośrodek Dokumentacji i Studiów Społecznych

Tokarczuk I. 1988, „Moc i wytrwałość”, wyd. 2, Kraków 1988: Znak

Wierzbieniec W. 2005. „Instytucjonalizacja życia religijnego w Rzeszowie po II wojnie światowej”. Pp. 59-96 in Rzeszów dawny i współczesny. Społeczeństwo, edited by: K. Kaszuba, Z. Sokół, Rzeszów: Wydawnictwo Wyższej Szkoły Zarządzania

Województwo podkarpackie. 2011. „2011 - podregiony, powiaty, gminy”. Rzeszów: Urząd Statystyczny w Rzeszowie

Zdaniewicz W., Adamczuk L. 2000. „Wstęp”. Pp. 451-457 in: Kościół i religijność Polaków 1945-1999 edited by W. Zdaniewicz, T. Zembrzuski. Warszawa: Instytut Statystki Kościoła Katolickiego.

Sadłoń W., "Dominicantes i communicantes 2010". http://iskk.pl/kosciolnaswiecie/154-dominicantes-i-communicantes-2010.html

Urząd Miasta Rzeszowa, „llość mieszkańców na poszczególnych osiedlach”. http://www.rzeszow.pl/miasto-rzeszow/danestatystyczne/ilosc-mieszkancow-na-poszczegolnych-osiedlach

Urząd Miasta Rzeszowa, „Jak rosło nasze miasto?”. http:// www.rzeszow.pl/ rozszerzenie-granic-miasta/jak-rosło-nasze-miasto Interviews:

Wywiad (W-1) z emerytowanym biskupem diecezjalnym przeprowadzony w dniu 20 sierpnia $2010 \mathrm{r}$.

Wywiad (W-2) z emerytowanym proboszczem parafii farnej pw. św. Wojciecha i Stanisława w Rzeszowie przeprowadzony w dniu 14 października $2010 \mathrm{r}$.

Wywiad (W-8) z proboszczem parafii pw. Świętego Krzyża w Rzeszowie przeprowadzony 16 września 2010 r.

Wywiad (W-10) z emerytowanym proboszczem parafii pw. Chrystusa Króla w Rzeszowie przeprowadzony 1 września 2010 r.

Wywiad (W-19) z proboszczem parafii katedralnej pw. Najświętszego Serca Jezusowego w Rzeszowie przeprowadzony 31 sierpnia $2010 \mathrm{r}$.

Wywiad (W-21) z proboszczem parafii pw. Matki Bożej Różańcowej w Rzeszowie przeprowadzony 8 września 2010 r.

Wywiad (W-22) z proboszczem parafii pw. Podwyższenia Krzyża Świętego w Rzeszowie przeprowadzony 6 września 2010 r.

Wywiad (W-23) z emerytowanym proboszczem parafii pw. św. Judy Tadeusza w Rzeszowie przeprowadzony 7 października 2010 r.

Wywiad (W-27) z proboszczem parafii pw. św. Michała Archanioła w Rzeszowie przeprowadzony w dniu 2 września 2010 r.

Wywiad (W-28) z proboszczem parafii pw. Miłosierdzia Bożego w Rzeszowie przeprowadzony 7 września 2010 r.

Wywiad (W-36) z proboszczem parafii pw. św. Jacka w Rzeszowie przeprowadzony 30 września 2010 r. 